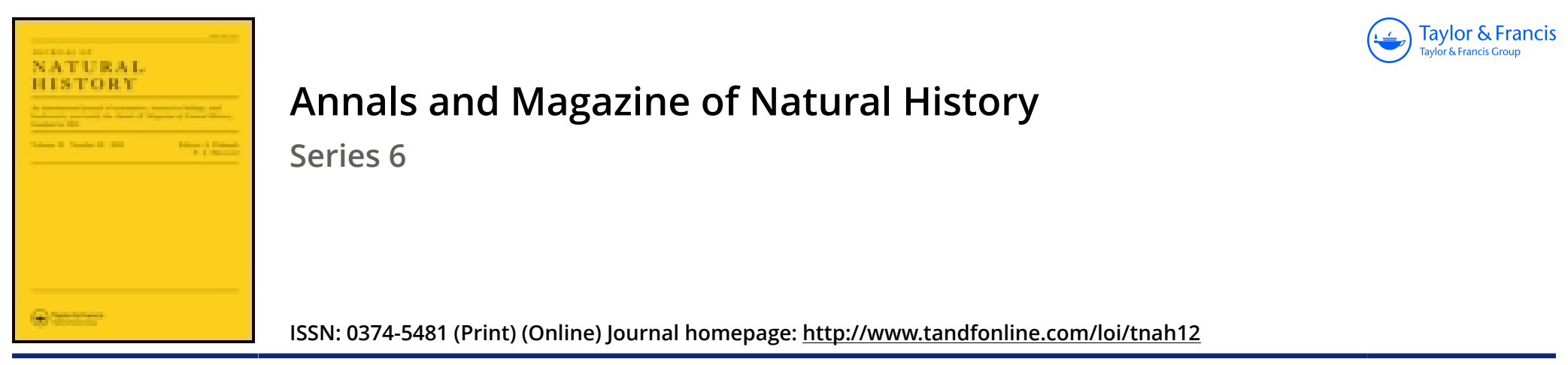

\title{
XLVII.-Short life-histories of nine Australian Lepidoptera
}

\section{A. Sidney Olliff}

To cite this article: A. Sidney Olliff (1888) XLVII.-Short life-histories of nine Australian Lepidoptera, Annals and Magazine of Natural History, 1:5, 357-362, DOI: 10.1080/00222938809460744

To link to this article: http://dx.doi.org/10.1080/00222938809460744

曲 Published online: 12 Oct 2009.

Submit your article to this journal $\sqsubset \pi$

Џ Article views: 3

Q View related articles $\asymp$ 
XLVII.-Short Life-histories of nine Australian Lepidoptera. By A. Sidney Olliff, Assistant Zoologist, Australian Museum, Sydney.

\section{[Plate XX .]}

THe following pages contain notes and descriptions of larvæ observed in the immediate neighbourhood of Sydney, drawn up with the view of supplying some little information about the early stages of such species as $I$ have succeeded in rearing during the past year. As few collectors in Australia have turned their attention to the earlier stages of the Lepidoptera, any resident entomologist with time and inclination for the work would have an almost untrodden field in this direction. Of the ten larvæ which $I$ have reared, as far as I am aware only one, namely Brunia replana, has previously been observed, although my larva-collecting scarcely extended beyond the limits of a single garden at Double Bay, one of the innumerable indentations of Port Jackson.

\section{Papilionidæ.}

Papilio sarpedon, Linn., var. choredon, Feld. (Pl. XX. fig. 1.)

The larva when very young is of a velvety black colour, with numerous spines, somewhat resembling those of many Nymphalidæ. On the shoulders two much larger spines fringed with hairs, and two at the anal extremity pure white. As the larvæ increase in size they lose the whole of the spines with the exception of two on each side of the first three segments * and the two at the tail, the colour of the insect now being of a dull sap-green above, merging into a bluish ashy hue on the sides; on the third segment, between and connecting the two spines, is a bright yellow band. These colours, although decreasing in intensity and becoming finely speckled with white, are continued until the insect is full-grown. The spines, however, become smaller and the lateral band of yellowish white in the region of the stigmata much more distinct. The adult larva is robust anteriorly, gradually tapering to the tail, in length about $1 \frac{3}{4}$ inch, and possesses retractile tentacula.

* In this and the folluwing descriptions the head is considered separately und the segmonts are counted anteru-posteriorly from one to twelve. 
Ann.\& Mag. Nat. Hist. S. 6.Vol.I.Pl.XX.

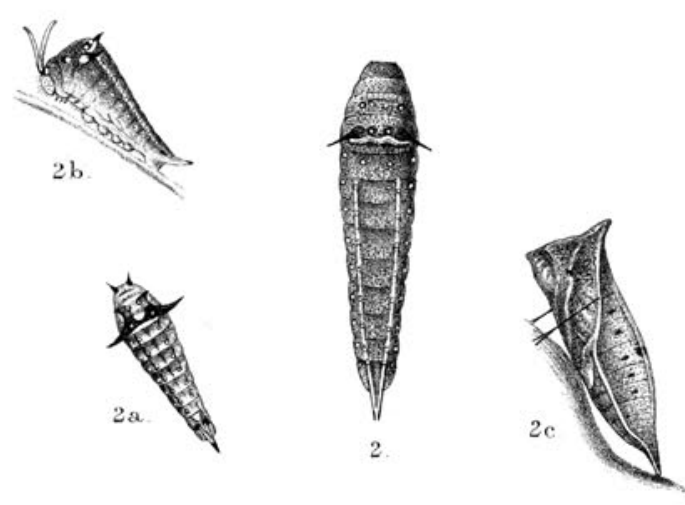

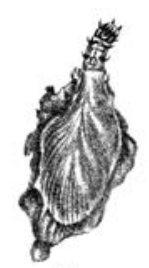

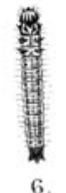

$6 a$.

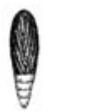

$6 b$.

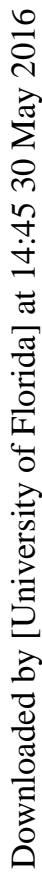
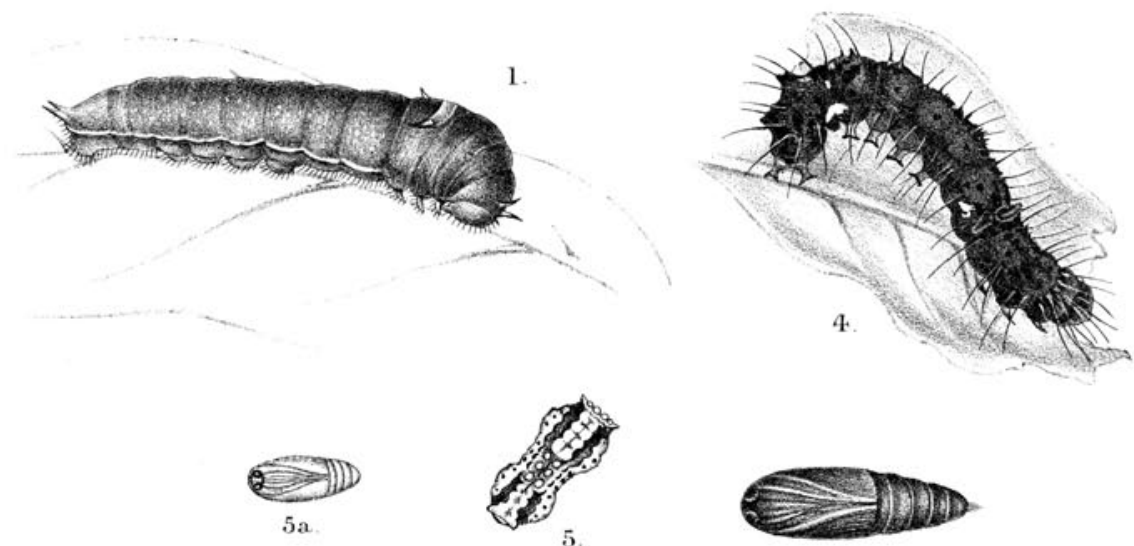

$4 \times a$.
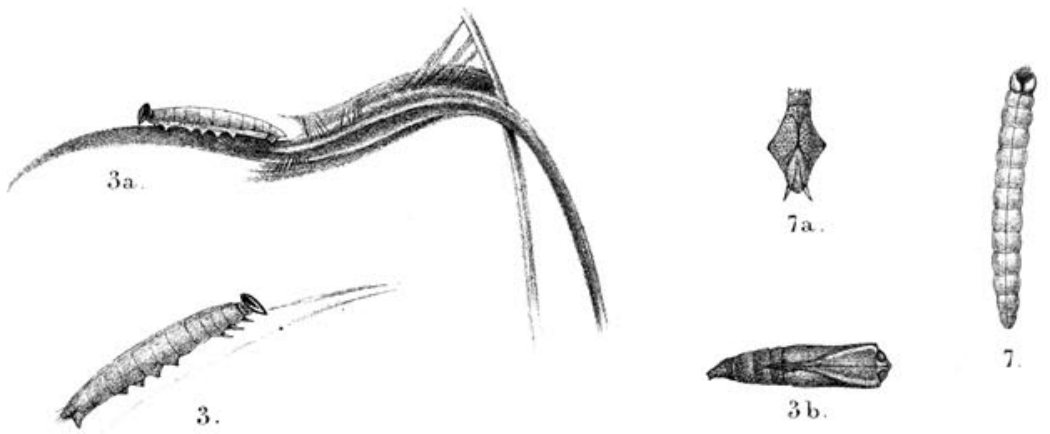

$3 \mathrm{~b}$. 
The pupa is attached by the tail and a central band, about $1_{\frac{1}{4}}$ inch in length and throughout of a pale green, finely speckled with darker. Over the head there is a projection or process of considerable length, from which emanate four conspicuous brown lines, which proceed two on each side until they meet at the tail.

'I'his species is common in open sunny places, such as gardens and waste grounds where flowering-plants occur. Its food is the camphor-laurel, on which the parent insect deposits the eggs singly.

Owing probably to the copious rains which have fallen during the past summer and the consequent luxuriant vegetation Papilio sarpedon and many other butterflies have been unusually abundant. One conspicuous species, Delias argenthona, never before observed by the Sydney collectors, has been comparatively common. It will be interesting to see if the species has permanently established itself; in Queensland it is one of the most abundant of the Pierina, but hitherto, I believe, the Clarence River has been the southernmost limit of its range.

\section{Papilio Macleayanus, Leach. (Pl. XX. figs. 2-2c.)}

The young larva of this species, which $I$ found in April feeding on the tender shoots of the orange, is whitish in colour, with the sides velvety brown; the head, second, third, eleventh, and twelfth segments black; each segment except the first and last provided with small, black, bifid bristles; the first, second, third, and last segments with large black tubercles. At the first moult the larva loses the bifid bristles and the tubercles assume the appearance of black spines, the anal one white at the base and bifid; the larva is now of a delicate green colour, somewhat speckled, with the head yellowish green, the anterior segments pale yellow, and the tail reddish. After the second moult, which took place in about a week from the time of hatching, it became perceptibly larger and more brightly coloured; the head turning yellowish green and the anterior spines, together with the space between them, reddish black. It is in this stage I believe, but on this point I am not quite sure, that the retractile tentacula are first perceptible; they are long, soft, and greenish in colour. At the third moult the ground-colour is much yellower and the green more pronounced, with two distinct rows of white spots on each side, the spines less conspicuous, and the anal horn yellow, tipped with black, and 
no longer bifid. Fourth change:-Colour similar but brighter, the spines on the first and second segments almost obsolete, and the line connecting the dorsal row of white spots greatly intensified.

This larva is very sluggish in its habits, but it is extremely sensitive, shooting out its tentacula at the slightest alarm.

Like the larva the pupa varies much in general colour; sometimes it is bright emerald-green and sometimes bluish white.

The butterfly, which is by no means common, made its appearance in August.

\section{Papilio erectheus, Don.}

This larva I found on a young orange-tree. When young it is marked with alternate patches of glossy brown and white, the brown predominating, and the body covered with conspicuous spines. As the larva increases in size its markings change; when adult it settles into a dull green, with large irregular patches of brown, strongly edged with white, generally three on each side. The spines now appear small, not having increased in the same proportion as the insect. The underside of the abdomen is dull white, except the first four segments, which are brown. The larva, which attains a length of $3 \frac{1}{2}$ inches, is furnished with the dorsal tentacula usually found in the Papilionidæ, and is very sluggish.

Pupa light green in colour, delicately speckled with black and occasionally with silver; a bifid projection at the head. Length varying from $1 \frac{3}{4}$ to $2 \frac{1}{4}$ inches.

'This is the commonest Papilio and the largest butterfly found in Sydney, where it occurs throughout the summer, occasionally in such numbers as to cause considerable destruction in orange-orchards. It also feeds on Xanthoxylum.

\section{Acræidæ.}

\section{Acroa Andromacha, Fabr.}

The larva when adult measures $1 \frac{1}{2}$ inch and is of a yellowish-brown colour throughout; each sezment bears a whorl of six black tubercles, each emitting a long branched spine.

Pupa about an inch in length, suspended by the tail; the thorax and abdomen cream-coloured, the latter with five longitudinal rows of yellowish spots edged with deep black; 
the wing-cases slightly brown, with black markings, and somewhat angulated.

Extremely abundant on the hybrid passion-vine (Tacsonia Mortii) in gardens at Darling Point. My specimens took wing in March.

\title{
Hesperidæ.
}

\author{
Apaustus agraulia, Hew. (Pl. XX. figs. 3-3 b.)
}

Larva pale green, darker at the sides, considerably narrowed posteriorly; the head dark brown, with a white Vshaped marking in front; the lateral line very indistinct. Length of adult 11 lines.

Pupa grey, semitransparent.

Fed on couch-grass, at the roots of which it pupated during March. The butterfly appeared early in April.

\section{Hypsidæ.}

\section{Hypsa nesophora, Meyr. (Pl. XX. figs. 4 \& 4 a.)}

Larva dark brown, somewhat shining, clothed with long bristly grey hairs; two conspicuous white spots on the sides, one between the fourth and fifth, the other between the ninth and tenth segments. Legs reddish, feet dark brown. Adult nearly 2 inches in length.

Pupa dark brownish red.

Fed on native fig, the larva living gregariously under a loosely made web. T'urned to a pupa in April, but the moth did not emerge until December.

\section{Ecophoridæ.}

\section{Philobota bimaculana, Don. (Pl. XX. figs. 6-6 b.)}

Larva about $7 \frac{1}{2}$ lines in length, bluish white, sparingly clothed with fine grey hairs; the head and a moderately large spot on each side of the second, third, and last segments dark brown; a row of small brown spots on each side of the dorsal surface extending from the fourth segment to the anal extremity.

Pupa reddish brown, the abdomen bright red.

Fed on Eucalyptus; living within a shelter formed by 
spinning the leaves together. Changed to a pupa in January, the moth taking wing on the 15th of the following month.

I believe this is the first record of the early stages of this extensive Australian genus.

\section{Depressariidæ.}

Gonionota pyrobola, Meyr. (Pl. XX. figs. $7 \& 7$ a.)

Larva about an inch in length, delicate blaish green in colour, the second segment more robust than the others; the head dark brown, having on each side an oblong patch of dull white. It lives at the end of the leaf in a tube, which it ingeniously constructs by cutting the leaf on each side from the outer margins to nearly the middle and rolling the upper portion on itself and securing it firmly with silk threads. Before entering the pupa state it leaves this habitation and attaches itself to the back of a leaf or small twig by the tail.

Pupa naked, dark bluish green, finely speckled with red; the shoulders prominent and angular; a rounded protuberance on the upper part of the front of the abdomen formed by the tips of the wings; two pointed processes above the eyes, projecting forwards, the tail truncated.

A single specimen of this remarkable species reared from a nearly full-grown larva found on AEgiceras fragrans in September last. The moth, which is nocturnal, emerged in January.

\section{Hyponomeutidæ.}

Encemia camincea, Meyr. (Pl. XX. figs. 5 \& 5 a.)

The larva of this species is of the form locally known as a "saddle-back." In colour it is white with traces of red, the sides yellow, with four longitudinal dark reddish-brown markings, two at the anterior and two at the posterior extremity, and a row of small brown spots parallel to each lateral margin. Length 7 lines.

Pupa yellow. Attached to the underside of a leaf on its food-plant.

A female specimen bred in April from larvæ found on a low-growing Eucalyptus in a garden at Double Bay.

\section{EXPLANATION OF PLATE XX.}

Fig. 1. Larva of Papilio sarpedon.

Fig. 2. Larva of Papilio Macleayanus. 2 a. Ditto, after third moult. 26 . Ditto, with tentacula protruded. $2 \mathrm{c}$. Pupa. 
Fig. 3. Larva of Apaustus agraulia. 3a. Ditto, with covering formed of leares. $3 b$. Pupa.

Fig. 4. Larva of Hypsa nesophora, 4 a. Pupa.

Fig. 5. Larva of Encemix caminea. 5a. Pupa.

Fig. 6. Larva of Philobota bimaculana. $6 a$. Ditto, with covering formed of leaves. $6 b$. Pupa.

Fig. 7. Larva of Gonionota pyrobola. 7 a. Pupa.

\section{XLVIII.-On a new Mode of Life among Medusae. By J. Walter Fewkes *.}

Several pamphlets and one or two books have been written on the influence of parasitism in the modification of animal structure. Perhaps nowhere do we find this mode of life better illustrated than among certain of the Crustacea, where the anatomical structure is so masked by their parasitic habits that for a long time in the history of research it was impossible to recognize their zoological affinities, and it was only when the immature stages in the growth were studied and larval conditions, unaffected by parasitism, had been investigated, that the true relationships of the group could be discovered.

What we find in the so-called Lernean worms exists wherever parasitism is found among animals. It may, in fact, be concluded that ordinarily in parasites there is a degradation in structure, or at all events such a modification as to lead to important changes in anatomy and external form.

It would seem that among the lowest animals we ought to find a larger number of parasitic genera than among the higher. While there is little doubt that there is more variety in lower animals, I am not so confident that this mode of life has led to as great modifications in structure here as might be expected. While we cannot ascribe to parasitism the many variations in animal structure which occur, and it is impossible to give this mode of life a primary importance in theories of origin of species as has been attempted, it is no doubt true that many variations in structure have been derived either directly or by heredity from parasitic ancestors.

Nowhere among lower animals is there more likelihood

* From the 'Proceedings of the Boston Society of Natural History,' vol. xxiii. Communicated by the Author. 